\title{
WHICH IS THE CHIEF CHIEF JUSTICE - DAVID LYNCH SCOTT OR HORACE HARVEY?
}

\author{
W.F. BOWKER*
}

The creation of the Judicature Act in Alberta in 1919 and its amendments in 1920 led to a period of profound confusion within Alberta's judicial system. Two men, David Lynch Scott and Horace Harvey, were at the centre of this confusion. By exploring personal letters written by Horace Harvey and others, Dean Bowker exposes how the wo judges and others behaved and felt as the question of who was the real Chief Justice in Alberta was argued through the Supreme Court and finally to the Privy Council. The letters illustrate that although this was a difficult time for the two men, hoth treated each other with respect and did what they could to ensure that the issue did not turn into a personal battle between themselves.
La création de la Judicature Act en Alberta en 1919 et ses modifications en 1920 ont entraîné une période de profonde confusion au sein de l'appareil judiciaire de la province. Deux hommes, David Lynch Scott et Horace Harvey, se trowaient au caur de cette confusion. En étudiant la correspondance de Horace Harvey et d'autres intervenants, Dean Bowker montre comment les deux juges et d'autres personnes se sont comportés et ont réagi quand il a fallu déterminer qui était vérifablement le juge en chef de r'Alberta - de la Cour suprême jusqu'au Conseil privé. Les lettres illustrent que, malgré que cette période ait été difficile pour les deux hommes. ils se som traités avec respect et ont fait tout leur possible pour éviter que le problème ne se ransforme en conflit personnel.

\section{TABLE OF CONTENTS}

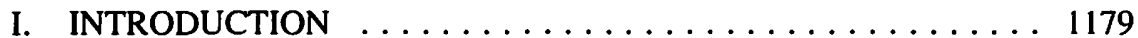

II. DAVID LYNCH SCOTT $\ldots \ldots \ldots \ldots \ldots \ldots \ldots \ldots \ldots \ldots 1180$

III. HORACE HARVEY $\ldots \ldots \ldots \ldots \ldots \ldots \ldots \ldots \ldots \ldots \ldots \ldots$

IV. SUPREME COURT OF ALBERTA ............ 1181

V. APPOINTMENT OF THE TWO CHIEF JUSTICES $\ldots \ldots \ldots \ldots 1184$

VI. HARVEY'S REQUESTS FOR A REFERENCE $\ldots \ldots \ldots \ldots \ldots 1185$

VII. THE REFERENCE - 15 FEBRUARY $1922 \ldots \ldots \ldots \ldots \ldots \ldots 1189$

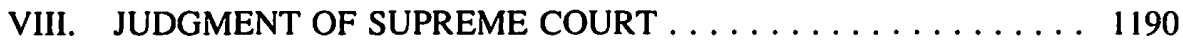

IX. SCOTT'S APPEAL TO PRIVY COUNCIL . . . . . . . . . . 1192

$X$. HARVEY'S APPOINTMENT AS CHIEF JUSTICE OF ALBERTA . . . . . . . . . . . . . . 1197

XI. CONCLUSION ........................ 1199

\section{INTRODUCTION}

This title is not the writer's. Frank Newson Q.C. asked this question in 1984. He used it as the title of an account (unpublished) that he wrote of the problem that arose in Alberta in 1921: was Horace Harvey still the Chief Justice of Alberta or had David Lynch Scott replaced him? The issue was created by Alberta legislation of 1919 and 1920 that provided for two separate divisions of the Supreme Court of Alberta - a Trial Division and an Appellate Division, each with a Chief Justice. Before describing this 
legislation and the problem it created, this essay will sketch the careers of the two judges involved.'

\section{DAVID LYNCH SCOTT}

David Lynch Scott was born at Brampton in Canada West (later Ontario) in 1845 and admitted to the Ontario bar in 1870 . He practiced in Orangeville and was mayor of that town shortly before moving in 1882 to Regina, the new capital of the Territories. He became Regina's first mayor. He had been active in the militia during the Fenian threat of 1866 . During the Riel Rebellion in 1885, he organized a volunteer corps and held the rank of Lieutenant Colonel.

At the trial of Louis Riel for treason, at Regina in 1885, he was one of five Crown counsel, the other four being from the East. After that trial, he prosecuted at Regina a number of other persons charged in connection with the Riel rebellion - Poundmaker, Big Bear, nine Cree involved in the Frog Lake massacre and the clash at Fort Pitt and five Indians connected with Duck Lake and Batoche. ${ }^{2}$

He continued to practice until 1894. In 1887, when the Supreme Court of the Territories replaced the Stipendiary Magistrates he hoped to be a member of the new court. On 2 March, Nicholas Flood Davin, the prominent Regina journalist, lawyer and politician, wrote to Sir John Thompson, Minister of Justice: "D.L. Scott Q.C. asks me to press his claim to a judgeship. I should be glad to have him appointed." ${ }^{3}$ The appointment came in 1894, to fill the vacancy in the Supreme Court resulting from the death of Colonel James F. Macleod. When that court was replaced by the Supreme Court of Alberta in 1907, Scott joined Chief Justice A.L. Sifton, Horace Harvey, C.A. Stuart and N.D. Beck, Scott being the senior puisne judge.

\section{HORACE HARVEY}

Horace Harvey was born at Aylmer in Canada West in 1863. His father was a Liberal member of Parliament for Elgin East in 1872-74. Horace went to school at Aylmer and later at Orangeville. He then attended the University of Toronto receiving a B.A. in 1886 and an LL.B. in 1888. He had as classmates a number who attained distinction and with whom he kept contact over the years. He was admitted to the Ontario bar in 1889 and practiced in Toronto for four years. In 1893, he was married and went to Calgary. He was enrolled as an advocate of the North West Territories in May. His partnership with Peter McCarthy was short-lived. He practiced by himself for a few months and was appointed Registrar of Land Titles at Calgary in December 1896. While in practice he

1. The letters cited in this article are from the papers of Horace Harvey M.G. 30, E. 87, Vols. 16-19. Public Archives of Canada. Manuscript Division. The writer is grateful to Normand Laplante. Manuscript Division, National Archives of Canada and the staff of the Archives for help in making available Chief Justice Harvey's papers. The research has been assisted by a grant from the Alberta Law Foundation. The writer is indebted to W.H. Hurlburt, Q.C. for comments on an earlier draft.

2. B. Beal \& R. Macleod, Prairie Fire: the 1885 North-West Rebellion (Edmonton: Hurtig, 1984). PAC, Sir John Thompson papers \# 5423, Reel C. 9240. 
had been active in the Calgary Liberal Association, serving as secretary. In the fall of 1899, Frederick Haultain offered him the appointment of Deputy Attorney General of the Territories.

Harvey accepted as of January 1900 and moved to Regina. In early 1903 he hoped for an appointment to the Territorial Supreme Court. When it was not forthcoming he seriously considered returning to practice at Calgary. He did however solicit and obtain the support of Frank Oliver, and in December A.L. Sifton, recently appointed as Chief Justice, indicated support and James Brierley of the Montreal Herald wrote a strong letter to Clifford Sifton and a similar one to the Prime Minister, Sir Wilfrid Laurier. The opening came in 1904 when the appointment of a fifth puisne judge was authorized. ${ }^{4}$

Harvey joined Chief Justice Sifton and Justices Wetmore, Scott, Prendergast and Newlands. He was assigned to Macleod. In 1907, as mentioned above, the Territorial Supreme Court was replaced by the Supreme Court of Alberta. Harvey moved to Edmonton.

Sifton resigned as Chief Justice in 1910 to become Premier of Alberta after A.C. Rutherford resigned because of criticism by members of his own party in connection with the Alberta and Great Waterways Railway. The Laurier government appointed Harvey as Chief Justice in his place.

\section{SUPREME COURT OF ALBERTA}

A word about the structure of the Supreme Court of Alberta. It was created by the Supreme Court Act of 1907 and consisted of a Chief Justice of Alberta and four puisne judges. All were trial judges. For appeals, they sat en banc though the judge from whom an appeal was taken could not act on the appeal from his judgment save in exceptional cases. ${ }^{5}$ In 1908, provision was made for a fifth puisne judge and a new provision said that three of the six judges should live at or near Edmonton and the other three at or near Calgary, though the Lieutenant-Governor in Council could grant leave to reside elsewhere. ${ }^{6}$

The provision for an extra judge was not proclaimed at once, and the puisne judges who served with Chief Justice Harvey were Scott, Stuart, Beck and a new appointee W.C. Simmons. In 1912, the extra judge was added - W.L. Walsh of Calgary, who was a brother-in-law of Scott.

In 1913, the number of puisne judges was increased to eight. Another amendment to the Supreme Court Act said "The Court en banc shall be known as the Appellate Division." Each December the judges were to select four of their members to constitute

3 Edw. 7, c. 27, s. 2 (Can.).

1907 , c. 3, ss. 30-35.

1908, c. 20, s. 18. 
the Appellate Division for the next year. ${ }^{7}$ The three new judges were appointed on 11 July, 1914 - M.S. McCarthy, W.C. Ives and J.D. Hyndman.

There was no change in the personnel for the next seven years. However the legislature in 1919 passed, but did not immediately proclaim,a new Act called the Judicature Act. ${ }^{8}$ Harvey himself drafted this Act at the request of the Attorney General J.R. Boyle. ${ }^{9}$ He had nothing to do with the two 1920 amendments. He did not know of them until later and once said they were passed behind his back. ${ }^{10}$ It will help to describe here the relevant sections of the $1919 \mathrm{Act}$ and then the 1920 amendments, which created the problem.

Section 3 of the 1919 Act continued the Supreme Court. Section 5 said it "shall continue to consist of two branches or divisions - Appellate and Trial". Then came section 6. It must be noticed because amendments to it in 1920 were at the heart of the question that arose. It said:

The Appellate Division shall continue to be presided over by the Chief Justice of the Court, who shall continue to be styled the Chief Justice of Alberta, and shall consist of the said Chief Justice and four other judges of the Court to be assigned to it by His Excellency the Governor General in Council and to be called Justices of Appeal.

Then section 7 dealt with the Trial Division. It consisted of a Chief Justice and five puisne judges. Section 9 said that the Chief Justice of the Court was to rank over all other judges and "the Chief Justice of the Trial Division shall have rank and precedence next after the Chief Justice of the Court."

These provisions posed no threat to Harvey's position. Indeed he inquired of the government as to when the 1919 Act would be proclaimed and J.R. Boyle, the Attorney General replied on 30 July 1920 to say that no decision had yet been made to proclaim the new Judicature Act and that the Court did not seem to be crowded. Harvey replied on 5 August that the courts were congested. More judges were needed.

The 1920 amendments were made on 10 April, though it must be remembered that the 1919 Act was not yet in force. The most significant amendment was made because of doubt in the minds of the federal authorities as to the validity of section 6 . Under the B.N.A. Act, a province can create courts but the appointment of judges to a superior provincial court is in the hands of the Governor General." Section 6 could be read as creating two new Chief Justices so that the appointment of each was in Ottawa's hands. Yet it was worded in a way that arguably meant that Harvey was the new Chief Justice of Alberta so that there was no appointment to be made of Chief Justice of Alberta, though of course an appointment had to be made of a Chief Justice of the Trial Division.

1913, c. 9,s. 38.

1919,c. 3.

Harvey to Eugene Lafleur, 25 May 1923.

Harvey to J.E. Atkinson, President, Toromto Star (17 March 1924).

B.N.A. Act, now the Constitution Act 1867, s. 92(14) and s. 96. 
The amendment took out the words "the Appellate Division shall continue to be presided over by the Chief Justice of the Court, who shall continue to be called the Chief Justice of Alberta" and replaced them by the words "The Appellate Division shall be presided over by a Chief Justice who shall be styled the Chief Justice of Alberta." That is to say, the definite article "the" was replaced by the indefinite "a."

This amendment was assented to on 10 April. It was itself amended by another amendment, found in the Statute Law Amendment Act. ${ }^{12}$ This last amendment specified that the Chief Justice "shall be Chief Justice of the Court."

These confusing amendments resulted in a section 6 that with verbal changes appeared in the Judicature Act, R.S.A. 1922, c. 72 as follows:

(1) The Appellate Division shall be presided over by a Chief Justice who shall be Chief Justice of the Court and shall be styled the Chief Justice of Alberta.

The Appellate Division shall consist of the said Chief Justice and four other judges of the Court to be assigned to it by His Excellency the Governor in Council and to be called Justices of Appeal.

The original sections 7 and 9 which established the Trial Division with a Chief Justice who ranked next after the Chief Justice of Alberta have been mentioned above. They were not amended in 1920.

Why were the 1920 amendments made? Because the federal government had advised the Alberta government that section 96 of the B.N.A. Act gave Ottawa the power to appoint both of the Chief Justices and that the original section 6 had the effect of taking away Ottawa's power to appoint one of them. This argument assumed that the amendments created a new position of Chief Justice of Alberta. ${ }^{13}$ If so, it followed that Chief Justice Harvey's position as Chief Justice of Alberta had been abolished and that a new position had been established under the same name.

The 1919 Act had not been proclaimed when a general election in Alberta was held on 17 July 1921. The Liberal government was defeated and the United Farmers of Alberta came into power. The Attorney General, J.R. Boyle was replaced by John Brownlee. On 11 August, the 1919 Act as amended was proclaimed and came into effect on September $15 .^{14}$

At the federal level, the Conservative Prime Minister Arthur Meighen was planning a general election. He appointed R.B. Bennett, who was not then in Parliament, to be Minister of Justice. He was sworn in on 21 September. His tenure lasted only until the

12. 1920 , c. 3, s. 2 and 1920 , c. 4 , s. 43.

13. See telegram of E.L. Newcombe, Deputy Minister of Justice to Harvey, 19 September 1921, infra.

14. A. Gaz. 15 August 1920 at 473. 
general election of 6 December when the Liberals defeated the Conservatives and W.L.M. King became Prime Minister. The new Minister of Justice was Sir Lomer Gouin, who had been Premier of Quebec.

\section{APPOINTMENT OF THE TWO CHIEF JUSTICES}

Returning to the date of 15 September, 1921 when the 1919 Judicature Act came into effect, the federal cabinet had ready its appointee as Chief Justice of Alberta and its appointee as Chief Justice of the Trial Division. On that very day, Scott was made Chief Justice of Alberta and Harvey was appointed as Chief Justice of the Trial Division. Appointed to the Appellate Division were Stuart, Beck, Hyndman and a new appointee, A.H. Clarke. The Trial Division judges were Simmons, Walsh, McCarthy, Ives and a new appointee T.M. Tweedie. The events of the next few days show that a delicate issue arose the moment the appointments of Scott and Harvey were announced.

The Appellate Division was to open its sittings on Monday, 19 September at Edmonton. On 16 September, Harvey sent a wire to E.L. Newcombe, The Deputy Minister of Justice:

Press reports appointment Scolt Chief Justice Supreme Court and me Chief Justice Trial Division. Presumably mistake. Alberta does not and could not affect my present office of Chief Justice of Supreme Court with style of Chief Justice of Alberta. It continues Supreme Court in two divisions and provides by amendments 1920 c. 3, s. 2 and c. 4, s. 43 that Appellate Division consists of Chief Justice of the Court to be known as Chief Justice of Alberta and four judges assigned. Federal Act ${ }^{15}$ provides for Chief Justice of Alberta and Chicf Justice of Trial Division. Sittings commence Monday. Please advise immediately.

Newcombe replied the next day, 17 September:

Government has proceeded upon the view that Alberta legislation constitutes new judicial offices which can be filled only by Governor General in Council including two Chief Justiceships in place of one as formerly. Section 6 of 1919 amended to meet objection raised by Ministers of Justice that local legislature could not limit the selection which devolves on Governor in Council; and government [interpreted] this section as it stands to require a new selection or assignment.

When the time came for the Appellate Division to open its session at 10 a.m. on Monday, 19 September, the Court room was crowded. However the judges did not appear. According to an account in that afternoon's Edmonton Journal, the Clerk of the Court came into court at 10:20 a.m. and announced that the opening was postponed until Wednesday. He added that the commissions had not yet arrived. Behind the scene, the four Justices of Appeal - Stuart, Beck, Hyndman and Clarke sent a wire to the Minister of Justice: 
Appellate Division scheduled to sit here this moming. All members of Court and crowded bar now present. Sitting prevented by conflicting claims to Chief Justiceship of the Court by Scott and Harvey. We the puisne judges desire to prevent unpleasant difficulty and cannot proceed with duties until arrangements made to have matter settled. If federal government will agree to refer dispute to Supreme Court matter can be arranged in the meantime. On this condition Harvey will consent to act in Trial Division until decision given. Court adjourned till Wednesday morning. Will government agree to make the necessary reference or take any appropriate proceedings to settle matter?

In a letter to Chief Justice Mathers of Manitoba on 7 October, Harvey said: "When the Appellate Court was about to open I insisted on my right to sit as the Chief Justice of the Court with the result that the four Justices of Appeal joined in a telegram to the Minister of Justice requesting him to make a reference..." The letter then set out Harvey's contention that he was still Chief Justice of Alberta. It asked for Mathers's opinion. At the end of this six page letter Harvey wrote: "There is also another matter which you may not have heard of but it is common rumour here now that it is understood that Scott will retire before the elections and that another judge, Beck being the most prominently mentioned, will be appointed Chief Justice of the Court in his stead". (Parenthetically, Mathers replied on 17 October. He agreed with Harvey's contention.)

\section{HARVEY'S REQUESTS FOR A REFERENCE}

What is a reference? When the Supreme Court of Canada was created in 1875 , the statute said "It shall be lawful for the Governor in Council to refer to the Supreme Court for hearing or consideration, any matters whatsoever as he may think fit; and the Court shall thereupon hear and consider the same and certify their opinion thereon to the Governor in Council...."16

Then, in 1891, the section was amended to provide: "The opinion of the Court upon any such reference although advisory only shall for all purposes of appeal to Her Majesty in Council be treated as a final judgment of the said Court between parties."17

The various provinces have legislation providing for references to the provincial Supreme Court. In 1912, the Privy Council ruled that this type of legislation was valid. In so holding, Earl Loreburn said: "But the answers are only advisory and will have no more effect than the opinions of the law officers." ${ }^{18}$ In 1956, the 1891 amendment was repealed, appeals to the Privy Council having been abolished in $1949 .^{19}$

Over the years many references have been made to the courts under the legislation and its provincial counterparts. Although the scheine has its drawbacks, it is still employed, particularly for questions as to the validity of legislation enacted or proposed. In theory,

16. 1875, c. 11, s. 52.

17. 1891, c. 25, s. 4 .

18. A.G. Ontario v. A.G. Canada, [1912] A.C. 571 at 589; see also Re Validity of Wartime Leasehold Regulations. [1950] S.C.R. 124 at 126 per Rinfret C.J. 
the answers are advisory only but "In practice reference opinions are treated in the same way as other judicial opinions." 20

We turn now to Chief Justice Harvey's request to the federal government for a reference to the Supreme Court. He made it in a wire to Newcombe on 19 September 1921. The next day Newcombe replied that "Government considers its authority to nominate President of Appellate Division sufficiently plain and not disposed to refer to Supreme Court of Canada." The following day, 21 September, Bennett was sworn in as Minister of Justice. The Edmonton Journal of that date referred to the "somewhat delicate situation" created by the appointment of Scott and added that many persons claimed Harvey was still Chief Justice. The same issue carried an account of events at the Edmonton Court House that morning. At 10:30 hours the Clerk of the Court went into the Judge's Chambers and came out announcing an adjournment "to 10:00 tomorrow". The same issue said "Yesterday the Lieutenant-Governor at the Parliament Buildings swore in Scott, Stuart, Beck and Clarke, Hyndman being absent." The report said that Harvey stated that he was not required to take the oath of office again. It was hoped a settlement would be reached soon. "The wires are hot between the Supreme Court and Ottawa."

The next day, Thursday, 22 September, the Journal reported that Harvey "explained the situation preliminary to the opening of the Appellate Division this morning." It was a plain and straight-forward statement. An explanation was needed. There was no personal animus. The only point was a purely legal one. Could the government appoint a new Chief Justice while another Chief Justice (Harvey) still held his commission? Pending settlement, Scott would preside over the Appellate Division and Harvey over the Trial Division. After this explanation, Harvey went to the Criminal Court while Scott, Stuart and Beck opened the Appeal Court. Harvey said that Scott's appointment was wellmerited because of his long service at bar and bench. ${ }^{21}$ On the opening of the Appellate Division, J.C.F. Bown, the City Solicitor, welcomed Scott "with a fitting tribute."22

After Ottawa's negative response to Harvey's request for a reference, he asked Brownlee, the provincial Attorney General to refer the question to the Alberta Court. On 21 October, Brownlee sent to Harvey a memo prepared by counsel in the department. It referred to a provincial Act for Expediting the Decision of Constitutional Questions. ${ }^{23}$ The counsel's opinion was that a reference might be made under that Act but that no appeal lay to the Supreme Court of Canada, and no appeal as of right to the Privy Council. The opinion then mentioned an ancient prerogative writ called quo warranto.

\footnotetext{
20. P. Hogg, Constitutional Law of Canada 2d ed. (Toronto: Carswell, 1985); also B. Strayer, The Canadian Constitution and the Courts: the Function and Scope of Judicial Review, 3d ed. (Toronto: Butterworths, 1988).

21. Harvey's conciliatory remark did not mean he acquiesced in Scott's appointment. He wanted to avoid the impression that the issue was a personal one.

22. The Edmonton Bulletin, a morning paper, carried on Friday 23 September a similar account of the events of 22 September. 
A person called the relator could ask the Crown to question the validity of the appointment of another person to a public office.

Harvey replied on the 26th. He agreed that there was no appeal to the Privy Council as of right but thought an appeal might lie if the Alberta Court gave leave. He also said quo warranto might lie but the question should not appear to be a controversy between judges. Quo warranto would make the question into a controversy and so would a proceeding for a declaration under Dyson v. Attorney-General. ${ }^{24}$

At this same period (namely on 14 October), Harvey wrote Newcombe to put forward his formal position:

\begin{abstract}
My contention is that my commission which bears date 12 October 1910 and appoints me to be Chief Justice of the Supreme Court of Alberta with the style or title of the Chief Justice of Alberta is still in force and effect because the Judicanure Act passed...in 1919, first. does not intend to affect it; and secondly could not do so by reason of the provisions of the B.N.A.ACt... The Act continues the Supreme Court of Alberta. It certainly does not alter the Province of Alberta and the Chief Justice of Alberta both before and after the Act is necessarily Chief Justice of the same Alberta....In order that the work may be properly performed I am for the present conducting trial work while Mr. Justice Scott sits in the Appellate Division where even as the senior puisne judge he naturally and properly presides. One reason for my doing this is a consideration for his age and his long standing as a member of the Court as well as the expectation that the legal question of my status will be brought before the Courts for determination within a reasonable time.
\end{abstract}

He ended by saying he did not acquiesce in the action of the federal executive.

On 22 October, Newcombe acknowledged Harvey's letter by wire and said he would submit it to the Minister of Justice, R.B. Bennett. Harvey and Bennett were not on cordial terms. ${ }^{25}$

At this same period Harvey consulted S.B. Woods, an eminent Edmonton lawyer who was a friend of Harvey and his solicitor (as well as solicitor for the University of Alberta, of whose Board Harvey was Chairman). In October, Woods was in Quebec, and he consulted Eugene Lafleur, the great Montreal advocate. On 15 October, Woods sent to his partner Sem Field this message: "Lafleur and I in conference agree that proper form of action ... is for declaration against Attorney General of Canada and the occupant of office ... I think best not to force a deadlock or scene by insisting on taking seat on appellate bench." If Scott were to resign, the action should be against the Attorney General of Canada only - but Harvey should try to get Department of Justice to submit a case so as not to force Harvey to take action. ${ }^{26}$

24. [1911] I K.B. 410. This is a leading case on the power of the Court to give a declaratory judgment; see the Judicature Act 1919, c., 3 s. 35. For quo warranto against a Saskatchewan Surrogate Court judge see Re Hannon, [1920] 2 W.W.R. 513.

25. J. Gray, Talk to My Lawyer!: Great Stories of Southern Alberta's Bar and Bench (Edmonton: Hurtig, 1987) at 32-33.

26. Vol. 17, $1921 \mathrm{~W}$. 
Harvey took care to see that he did nothing that could be construed as acquiescence in his appointment as Chief Justice of the Trial Division. On October 10, M.A. Kelly, the cashier in the Calgary court, addressed a letter to Harvey as "The Honourable Chief Justice Trial Division." Four days later Harvey acknowledged the letter and said: "It will be surer and more accurate to address me as Chief Justice Harvey as in the past." Then on the 17th of October Walter Scott, the Legislative Counsel wrote Harvey a letter in connection with the revision of Alberta's statutes, in which each was involved along with several others. (The revision appeared in 1922.) The letter was addressed to "the Honourable the Chief Justice, Trial Division of the Supreme Court of Alberta." Harvey replied on 20 October: "I would suggest that any future communications should be addressed to me as Chief Justice Harvey, since as you are probably aware I claim no right to the title you have used." The next day Scott replied to say "I had no knowledge whatever of the address placed on your letter." He made a contrite apology and ended "Deeply regretting the incident and still more regretting the ready attribution to me of an intention to be impertinent."

The same day Harvey wrote a conciliatory answer. He said "This is only the second letter which I have received addressed in this form, and somewhat singularly they are both from officers of the provincial government, and I naturally thought there might be something involved in that." He explained that he would not accept a commission as Chief Justice of the Trial Division because if he did it would be treated as a relinquishment of the other office, and he "deemed it necessary to do nothing that was a waiver of my position." On 24 October, Scott sent a gracious reply.

At this time, namely on 13 October, the Under Secretary of State wrote Harvey to say he was sending "under separate cover a commission under the Great Seal appointing you Chief Justice of the Trial Division of the Supreme Court of Alberta and ex-officio a Judge of the Appellate Division of the said Court." On 17 October, Harvey acknowledged receipt of the letter and commission. "I do not desire to treat this commission as in any way affecting [my position] as I consider myself to be Chief Justice of the Supreme Court of Alberta ... by virtue of my appointment to that office by commission eleven years ago with all the authority of that office."

In the next few weeks there were no new developments so far as the Harvey papers show. However one important event occurred on 6 December - a general election. The Meighen government was defeated and Mackenzie King was sworn in as Prime Minister on 29 December. R.B. Bennett was of course no longer Minister of Justice and indeed lost his seat. ${ }^{27}$ The new Minister of Justice was Sir Lomer Gouin, who had been premier of Quebec.

At the end of the year, Harvey and his legal advisers were still trying to persuade the federal government to refer the issue to the Supreme Court. On 30 December Lafleur wired Harvey: "Woods and I agree to refer matter to Supreme Court independently of personal element." The Justice Department still objected to a reference to the Supreme 
Court, and on 27 January 1922 Newcombe wired Lafleur in order to set out his objections. The next day Lafleur replied to say that he argued for a reference because the independence of the judiciary was at stake. Then on 2 February Lafleur wrote Woods to say it was cruel to leave Harvey without redress except by suing Scott. The government should be shamed into a better attitude.

\section{THE REFERENCE - 15 FEBRUARY 1922}

On 4 February, Harvey wired Prime Minister King to say he would prefer a reference. "I would be obliged if you can help it along." On the 13th King replied to say he had spoken to Gouin. "Sir Lomer informs me that he has dealt with the matter in accordance with your wishes." On 10 February, Lafleur wired Woods to say that the Order in Council for a reference had been signed that day and on 14 February he sent Harvey the same message. The Order in Council was dated 15 February. It set out Harvey's letters patent of 1910 and those of both Harvey and Scott in 1921. Then it asked five questions:

(1) Are Scott's letters patent effective to make him Chief Justice of Alberta?

(2) If not effective for all purposes, to what extent are they ineffective?

(3) Are Harvey's letters patent of 1921 effective to make him Chief Justice of the Trial Division?

(4) If not effective for all purposes, to what extent are they ineffective?

(5) Is Harvey by virtue of his 1910 letters patent Chief Justice of the Appellate Division and what judicial office does he hold beyond that provided in his 1921 letters patent?

Harvey had some concern over the form of the questions. On 18 February, he wired Lafleur that the form of the reference implied that the controversy was between two judges, but added that probably this was of no consequence. The facts were shown by attaching the commissions.

On the same day he wrote to the Honourable Charles Stewart who had been premier of Alberta and now was Minister of the Interior in King's government. Harvey wanted the Minister of Justice to retain counsel for each side. He gave two reasons: (1) the Dominion government was responsible for the situation which made the reference necessary and (2) for the proper administration of justice, it should not appear to be a contest between two judges. The federal government did not meet this request.

On 28 February, the Attorney General of Canada applied to the Court for directions relating to the hearing on the five questions. Present were Justices Idington, Anglin, Brodeur, Mignault and Sir Walter Cassels ad hoc. After hearing counsel for the applicant and for Harvey, the Court ordered (1) that the case be inscribed for hearing at the end of the Ontario list at the present session, (2) that the Attorney General of Alberta and Harvey 
and Scott be notified of the hearing and (3) that they be entitled to appear in person or by counsel on the argument.

\section{JUDGMENT OF SUPREME COURT}

The reference was argued on 14 and 15 March before all six judges of the Supreme Court - Chief Justice Davies and Justices Idington, Duff, Anglin, Brodeur and Mignault. Two counsel appeared - Newcombe for the Department of Justice and Lafleur for Harvey. Scott was not represented though Newcombe supported the validity of Scott's appointment as Chief Justice of Alberta. Judgment was delivered on 2 May. ${ }^{28}$

Chief Justice Davies answered the questions in Scott's favour. The 1919 provisions would have preserved Harvey's 1910 commission but the 1920 amendments negated that result.

Justice Idington's answers were in essence the same as the Chief Justice's. When the 1919 Act as amended came into force on 15 September 1921, it created two new courts and new judicial offices. The Governor General had the power to fill those offices.

The other four judges gave answers in Harvey's favour. Justice Duff thought that although the amended section 6 could be read as doing away with the previous office of Chief Justice of the Supreme Court, it need not be so read. It could be construed as prescribing duties among existing judicial offices. Thus he held that Harvey was Chief Justice of the Supreme Court of Alberta.

Justice Anglin mentioned the embarrassment in requiring the court to express an opinion as to which of two gentlemen held the highest judicial office of Alberta. He added that one was represented by counsel, "the other, though duly notified, having, as was his right, declined to appear." Then he said "Nor is our embarrassment materially lessened because our answers are only advisory and will have no more effect than the opinions of the law officers."

On the interpretation of the 1919 Act as amended in 1920, he mentioned Newcombe's argument "that these amendments predicated an intention to create five appellate judgeships as new positions to be filled by the Governor General in Council." Anglin answered this by pointing out that sections 3 and 5 of the Act enacted in 1919 remained unamended, and provided that the existing court and divisions were expressly "continued." Thus it was impossible "to contend successfully either that a new Supreme Court was established or that new divisions of that court were constituted" and "It is I think equally impossible to maintain that all the existing judicial positions in the Supreme Court were abolished and eleven new Supreme Court Judgeships created" with the result that all the judges "might have been superseded and a judiciary consisting of an entirely new personnel appointed by the Governor General in Council." Justice Anglin concluded that 
the only new offices were the Chief Justiceship of the Trial Division and an additional puisne judgeship of the Supreme Court.

Justice Brodeur held that Harvey was appointed Chief Justice in 1910 and that that office was continued and maintained by the new legislation of 1919 and 1920 .

Justice Mignault gave a useful account of the history of the legislation that established the Supreme Court of Alberta. He recognized that after the 1919 Act was amended in 1920 one could argue that the intent was to create a new office of Chief Justice of the Supreme Court of Alberta but Mignault declined to "give the preference to a construction that would deprive the existing Chief Justice of the Supreme Court of his high office and possibly leave the Governor in Council free not to appoint him to any judicial office."

On May 2, 1922, the day the judgment came out, Harvey wrote to Scott at Victoria to say that the assignments of judges should not be affected by the decision. "I would be glad if you will continue to preside over the Appellate Division." Harvey was prepared to go back to trials for a while longer. Scott did not reply. On 20 May, Harvey wrote to Gouin. He referred to Newcombe's argument before the Supreme Court that the opinion of the Court could not revoke Harvey's 1921 commission. Assuming it to be correct, Harvey wanted to make it clear that he expressly disclaimed all interest under such commission. His 1910 commission should be recognized as superior to the 1921 one.

On 21 June, Harvey wrote again to Gouin (and he wrote the same letter to Alberta's Attorney General, John Brownlee).

When the decision was given Mr. Justice Scott was in Victoria. I at once wrote him suggesting that he should continue to preside in the Appellate Division and that I would continue with and finish my trial assignments. I received no acknowledgement of my letter but he returned in two or three weeks and is sitting in the Appellate Division. Not all the trial judges seem satisfied that I should prepare the fall assignments and today I spoke to Mr. Justice Scott in the presence of the Appeal judges about it. He said he had nothing to do with the trial assignments, that he was Chief Justice of the Appellate Division and that the decision of the Supreme Court of Canada was nothing but an opinion and did not affect his commission. If I intend to preserve my self-respect it seems necessary that I should no longer acquiesce in a position resting on what has been declared by the highest court to be a nullity. I told him that as Chief Justice of the Court I proposed to take my proper place in the Appellatc Division in the fall. He answered that if I did there would be an unholy row. I am therefore giving you this notice in ample time to have such action taken as you may deem desirable to prevent the occurrence of anything detrimental to the due administration of justice and in accordance with what I told Mr. Justice Scott I would do. I may add that when $I$ said to him that it never occurred to me that either of us would fail to show respect to the Supreme Court if a reference were made as the judges had requested he said he had never agreed to be bound by it. which of course, as I admitted to him is perfectly true.

\section{On 28 June Gouin replied:}

I have your letter of the 21 st instant ... from which it appears that Chict Justice Scolt does not intend to be guided by the majority opinion of the Supreme Court of Canada. 
At the time the reference to the Supreme Court of Canada was under consideration this contingency was foreseen and it was pointed out that as the opinion of the Court would be advisory only it would not affect Chief Justice Scott's commission nor subject him to any consequences for non-appearance or for refusal to be bound by it, and it was suggested that the proceedings should have been by quo warranto as in Buckley v. Edwards [1892] Appeal Cases 387.

He ended by saying there was nothing he could do "to obviate the difficulties of the present situation and that the remedy lies in the hands of the Attorney General of the province. If you are advised that there is any appropriate action which this government could take I should be glad to consider the matter further on hearing what it is."

On 20 July, Harvey wrote a lengthy answer. He said the Supreme Court's answers meant that Scott's appointment was a nullity. The federal government must accept the decision.

\section{SCOTT'S APPEAL TO PRIVY COUNCIL}

Scott decided to appeal to the Judicial Committee of the Privy Council. He retained R.B. Bennett as his counsel. He had to apply to the Judicial Committee for leave to appeal. ${ }^{29}$ The leave was granted on 10 August.

On 6 September, Harvey wrote to Prime Minister King. ${ }^{30}$ Referring to Newcombe's role in the reference to the Supreme Court, he complained that Newcombe acted like counsel for Scott and reported by letter to Bennett who passed the letter on to Scott. Harvey then quoted from the report of his London solicitors, Blake and Redden. ${ }^{31}$ The report said that on the application for leave to appeal Bennett appeared for Scott and Newcombe for the Dominion government. The Attorney General of Alberta and Harvey were respondents but were not represented. Harvey wanted King to have the Dominion government pay his costs before the Supreme Court of Canada and also to retain Lafleur to represent him before the Privy Council. He added that "some persons, perhaps friends of Beck, who hopes to succeed Mr. Justice Scott as Chief Justice of Alberta, have prejudiced Sir Lomer, whom I do not personally know, against me."

In a letter to Lafleur, on 14 September, Harvey said that Scott was far from well and unable to sit. Harvey was indisposed to take advantage of Scott's illness. "I shall leave the appeal work to be done by the other judges and go on with the trial sittings."

On 30 September, King wrote Harvey to say that Gouin was anxious to see justice done. Gouin arranged the reference which his predecessor (Bennett) had refused. The department did not meet Scott's request to appeal to the Privy Council. Scott entered the appeal.

The Imperial Order in Council of 1908 permitting the Supreme Court of Alberta to grant leave to appeal direct to the Privy Council (2 Alta L.R. 571) did not apply to appeals from the Supreme Court of Canada.

31. This firm had a large Privy Council practice and was the London agent of the Alberta government. 
At this stage Harvey was concerned about the costs of the reference and the appeal and his concern persisted for a long time. On 21 October, he wrote to the Honourable Charles Stewart. Harvey said that Gouin had not yet decided whether to bear the costs of Harvey's counsel. The Department of Justice should bear the costs before the Supreme Court of Canada regardless of the Privy Council decision. Newcombe was not impartial. $\mathrm{He}$ argued for Scott. Leave was granted by the Privy Council without security for costs. "I could ... decline to be represented.... In fact I sometimes feel so disgusted over the whole affair that I feel like throwing it all up and getting out." ${ }^{32}$

Stewart replied on 30 October to say he would see King and Gouin. He wrote Harvey on 21 November to say that Gouin was in a different frame of mind. "We have practically arranged that upon the retirement of Mr. Scott you will be assured of the position." On costs Gouin would consider paying costs of both "trials." On 7 December Harvey wrote to thank Stewart and to say he was instructing Lafleur:

My position is different from that of Mr. Justice Scoll who is himself taking the appeal to the Privy Council or who is rather no doubt allowing his name to be used for the purpose of permitting Mr. Bennelt to take the appeal for the purpose of showing his standing as a constitutional lawyer. ${ }^{33}$

On the same day, 7 December, Harvey wrote Lafleur to say that Bennett had told Tweedie $^{34}$ that the case was being printed for the next sittings of the Privy Council. Harvey went on to mention the matter of Lafleur's fee. He was not sure the government would pay it. "I feel most grateful to you for all you have done for me in the past and for your expression of willingness to do what you can without accepting any fee from me," but if the government failed to accept responsibility Harvey would pay Lafleur's outof-pocket expenses. He added that Scott was still sick. The Appellate judges were carrying on and Harvey was sitting in the Trial Division and arranging to continue there for the next term.

In the early months of 1923, there was a lull, at least in Harvey's correspondence. On 25 May, he sent to Lafleur a ten-page memo he had prepared on the history of the legislation, an analysis of the 1919 Act and its amendments, and then comments on the dissenting judgments. On 5 June, Lafleur, having received a copy of the "case" (i.e. the factum) of Scott and that of Newcombe for the Attorney General of Canada, sent Harvey the final paragraphs of the latter, which argued that the creation of the two divisions left open the Chief Justiceship of each. On 9 June, Harvey sent some comments on Newcombe's argument.

The appeal was argued on 14 and 15 July before Viscount Haldane and Lords Buckmaster, Atkinson, Shaw and Sumner. With Bennett was Geoffrey Lawrence who appeared in many constitutional appeals from Canada. He was a judge at the Nuremburg

32. On the question of costs on the reference to the Supreme Court the judgments said nothing about costs.

33. Vol. 18, 1922 P.R.S.

34. Mr. Justice T.M. Tweedie of Calgary. He had been a Conservative M.P. and was appointed to the Trial Division in 1921. 
war crimes trials and in 1947 became a Lord of Appeal in Ordinary as Lord Oaksey. Newcombe appeared for the Attorney General of Canada and Lafleur for Harvey.

On 17 July, Blake and Redden cabled Harvey to say "Bennett argued long. Newcombe professed not to take sides but did support Scott. Bennett persuaded Atkinson and Haldane. We do not know about Buckmaster, Sumner and Shaw. Lafleur very good. All turns on Buckmaster." Harvey acknowledged this message on 3 August.

A friend of Woods, a Calgary lawyer named C.H. Powlett, attended the argument and wrote Woods. He was hopeful that Harvey would succeed. Atkinson was for Bennett while Shaw was for Lafleur throughout. Haldane leaned toward Bennett while Sumner seemed to be with Lafleur. Buckmaster was against Bennett in the beginning but seemed to change. He added that Lafleur was wonderful. "He was like a diamond drill tipped with lightning - not a single waste word...he delivered a steady stream of beautifully directed rapier thrusts. ${ }^{135}$

The "judgment" of the Privy Council was technically advice to the King, ending with the statement "Their Lordships will humbly advise His Majesty accordingly." Only one piece of advice could be given. There was no place for dissents, though this practice was changed in $1966 .{ }^{36}$

The judgment was delivered on 18 October, 1923. Lord Atkinson wrote the opinion. It was not published in the Law Reports or in any other English reports so far as the writer can find, apart from a one-page summary. ${ }^{37}$ It did appear in the Western Weekly Reports $^{38}$ and in the Dominion Law Reports. ${ }^{39}$

The judgment takes up nine pages in the Western Weekly Reports compared to the forty-six pages in the Supreme Court Reports for the six opinions given in the Supreme Court of Canada. Lord Atkinson set out the five questions and the answers of the majority in the Supreme Court. Then he said that the question turned on the 1919 Act and the two 1920 amendments. He described the 1907 Supreme Court Act, Harvey's 1910 appointment as Chief Justice, the 1913 Act renaming the Court en banc as the Appellate Division, the 1919 Act and the two 1920 amendments, and finally the appointment of Scott and of Harvey on 15 September 1921. Lord Atkinson then took two paragraphs to explain the reasons for rejecting Lafleur's argument and the majority opinions in the Supreme Court. Lafleur had stressed the word "continue" in sections 3 and 5. Lord Atkinson replied that even if the old Supreme Court was continued the legislature was entitled to enact that the Court should consist of two divisions with a

35.

The writer of this letter was later a plaintiff, along with his son in Powlett v. University of Alberta, [1934] 2 W.W.R. 209. Woods acted for the defendant. Chief Justice Harvey was examined for discovery as an officer (Chairman of the Governors) of the University. This case may have put a strain on Powletl's friendship with Woods.

3. 1100.

37. Scott v. A.G. Canada, 40 T.L.R. 6.

3*. Scott v. A.G. Canada, [1923] 3 W.W.R. 929.

39. [1923] 4 D.L.R. 647. 
division of the business between them. The scheme "contemplates and, for its working requires the appointment of two Chief Justices." The fact that before the 1919 Act was passed the Chief Justice was Chief Justice of the Supreme Court did not prevent the Alberta legislature from dividing the business of that Court into two branches or necessarily entitle Harvey to be appointed Chief Justice of the Appellate Division. As to Harvey's argument that the non-appointment was an infringement of his legal rights, Lord Atkinson simply said there was no infringement of any legal right. He did not mention section 99 of the B.N.A. Act (judges shall hold office on good behaviour) or the reasoning of the majority in the Supreme Court.

The judgment ended "There will be no order as to costs."

Two days after the judgment Harvey wrote Lafleur to say that if the Dominion would not pay the costs he would. He commented on the judgment speculating on the grounds. Then he said "Whatever the ground there is nothing to be gained by further consideration and I feel no cause for concern because during the interval I have preserved my own selfrespect and I believe I have kept the respect of the profession which is much more important than the actual question of the office." In a hand-written postscript Harvey said "I hope there is foundation for the rumour that you are to go to the Supreme Court. Your presence there would add greatly to the respect for, and confidence in, the Court throughout Canada."

As to Harvey's own position, it is clear that he was thinking of retiring and going East, for Charles Stewart said in a letter to him of 18 December, 1923, "With regard to your own position - I have had the matter up with the Prime Minister and find that he is quite favourable to your coming East, and thinks there would be a very considerable amount of work for you if you decided to retire."

Three months later, on 21 March 1924, Harvey wrote to Stewart a letter addressed to Stewart's house. He commented on the fact that Newcombe had stated to the Judicial Committee that the Liberal government had approved of the action of the Meighen government and that this fact influenced the two ex-Chancellors (Haldane and Buckmaster) who naturally would look at the political side. Harvey then said that Scott had told him that he, Scott, would retire if his pension were increased, and that Beck's appointment to succeed him did not enter in. The notion that Scott would retire if Beck were appointed came from Beck or Bennett. Scott did say he would give Beck twomonths' notice but this did not mean that Scott would retire only if Beck were appointed. Turning to the matter of costs of the reference, Harvey said that Scott wanted the government to pay his. If so then the government should pay Harvey's.

On 26 March, Stewart replied. Referring to J.R. Boyle who had been Attorney General of Alberta and on the Liberal defeat in 1921 had become leader of the opposition, Stewart said that Boyle's friends were pressing hard to have him appointed to the Bench.

On 10 May, Stewart wrote again to Harvey who seemed to have written Stewart, for Stewart began by saying "I have your letter of the 2nd instant with reference to transfer to S.C.C." Stewart added "I shall be delighted to suggest your name but ... I fear it's a 
waste of time. The 'dear old East' is going to hang on to all the vacancies that may occur in which they are interested." He had made representations before, but they were in vain. Someone from the Maritimes will fill the vacancy created by the death of Sir Louis. (The reference is to Sir Louis Davies, Chief Justice of Canada, who had died on 1 May.)

Harvey must have replied, for Stewart wrote on 24 May to say that action to increase "the representation on the Supreme Court bench will be taken in the immediate future." (The next appointment to the Supreme Court was of E.L. Newcombe, the Deputy Minister of Justice, who had played such an important part in the Harvey/Scott issue. The number of judges on the Supreme Court was not increased from six to seven until 1927.)

Another revealing exchange of letters occurred around this time. On $17 \mathrm{March}, 1924$, Harvey wrote to a friend of his, J.E. Atkinson, President of the Toronto Star. $\mathrm{He}$ described the reference and suggested that political considerations had governed with the majority in the Privy Council. Then he referred to the possibility that Scott would retire and that Beck was seeking support for the appointment. He mentioned the rumour that efforts were being made by the Liberals to get rid of Boyle as opposition leader by having him appointed to the vacancy that would be created by Scott's retirement. Harvey then said:

I do know that Sir Lomer Gouin would have been quite willing to appoint Beck on Scott's retirement. and I have reason to believe that the present Minister of Justice [Emest Lapointe] is equally well disposed. I told Mr. Stewart that if Beck were appointed over me I would certainly consider it such an affront that I would resign, and I know that he is personally much opposed to it - but if the only way that a vacancy can be created to provide for Boyle is by making that appointment I am not sure how strong Mr. Stewart will be for I believe his life is being made miserable by complaints about the situation due to Boyle's leadership. The personal question of course enters into my consideration but I would have felt diffident about writing to you or anyone if that were the most important question for consideration. The fact is that Beck is a R.C. first last and all the time, on the bench and off the bench, and while a good lawyer and well-liked that fact certainly militates against his quality as a judge.

Harvey proceeded to give detailed examples. Then he referred to the 1920 amendments saying they were made "behind my back" and that they "made it possible for someone to be appointed over my head," and that the Liberal government at Ottawa had supported Scott on the reference. Moreover it had left Harvey to bear the costs.

I have no reason to consider that the present Minister of Justice is any more favourably disposed to me than his predecessor, especially where there is a R.C. judge in consideration.

In view of my personal interest in the matter however I felt somewhat diffident in writing to you. I have not written to anyone else but it appears to me that you are in a position where you can exert some influence with a beneficial result and that the matter involves something of much more importance than my personal interest.

Then he said that the Prime Minister has responsibility for appointing Chief Justices. 
On 17 March, Atkinson replied: "With reference to the matter about which you wrote me I shall look for the first opportunity of speaking a word where it will do the most good. Mr. King as you may know has been away from Ottawa for a week. I sincerely hope the new appointment will reinstate you in the position from which I regret very much you were elbowed away."

On the question of Harvey's costs, Blake and Redden charged Harvey only $£ 25$ for disbursements. On 26 November, 1923 Harvey wrote F.A.C. Redden, referring to him as an old friend from University of Toronto days. Then on 1 March 1924 Harvey sent the $£ 25$ and said "Again let me say how deeply I feel the kindness shown me by you as well as by all my brethren of the law in connection with this case. Even if I have lost the decision I have gained something which is well worth while."

As for Lafleur's disbursements they came to $\$ 64.96$. On 26 November, 1923, Harvey wrote him. "Permit me to express again my deep appreciation of your kindness and readiness to do what you have done without recompense. I do not consider it is quite fair and it seems a greater mark of friendship than I deserve."

The Privy Council judgment meant that Harvey was Chief Justice of the Trial Division and Scott Chief Justice of Alberta. Scott was in very poor health. However, it appears from Mr. Justice Beck's Judges Book that Scott did sit in the Appellate Division in early 1924 and as late as 23 June.

On 10 May, Harvey as Chairman of the Governors of the University of Alberta, wrote to Dr. Tory, the President, proposing an honorary LL.D. for Scott. "Chief Justice Scott is not a young man and for that reason I would urge that action be not deferred." The programme for the 1924 Spring Convocation on 15 May shows that the degree was conferred. Chief Justice Scott died on 27 July.

\section{HARVEY'S APPOINTMENT AS CHIEF JUSTICE OF ALBERTA}

Harvey was appointed on 27 August. He received some letters of congratulations on his appointment. J.R. Boyle who had been provincial Attorney General when the 1919 and 1920 amendments to the Judicature Act were made may have written a letter. At least Harvey wrote Boyle a letter that must have been a rejection of Boyle's congratulations. (Boyle was appointed to the Trial Division on the day Harvey was appointed Chief Justice (August 27)). Boyle wrote Harvey on 23 September.

I read your letter with both surprise and sorrow - surprise that one so successful could be so bitter in the hour of greatest triumph - sorry you have allowed yourself to be persuaded into thinking that I have in some way done you an injustice. Time however mellows bittemess and usually reveals the truth and often changes men's viewpoints as they look back. Let us hope it will be so in this case. I have received so many knocks in nearly 20 years of public life that now I am leaving politics for the more serene atmosphere of the Bench. A few more as I am going will not matter. ${ }^{41}$ 
Harvey had had differences with Boyle prior to this. In the spring of 1920 , there was a testy exchange of letters over a proposal to amend Rule 713 which permitted the judges to make rules of court - Harvey thought that the proposed change, requiring an Order in Council before judge-made rules would come into effect, showed lack of confidence in the judges.

In July of the same year, Harvey asked Boyle when the 1919 Judicature Act would be proclaimed. Boyle replied on $\mathbf{3 0}$ July to say that no decision had yet been made, adding that the Court did not seem to be crowded. Harvey replied on 5 August to say that the Courts were congested and that it was hard to fix the assignments.

Then just after Boyle ceased to be Attorney General and before he was appointed judge he defended a man charged with theft from the post office. He accused the two main Crown witnesses of a "frame-up." In his charge to the jury Harvey said there was no basis for Boyle's allegations. ${ }^{41}$

Then not long after Boyle became a judge, he found for the plaintiff wife in an alimony action. He believed her evidence and disbelieved the defendant's. On the husband's appeal, Harvey said that the plaintiff was not worthy of belief. The trial judge was unjustified in refusing to believe the defendant's evidence. He added this: "He [the defendant] does resent, however, the strictures and contemptuous references and findings of desertion and perjury by the learned trial judge and I think he is justified in so doing, for, in my opinion they are entirely unwarranted by the evidence. ${ }^{42}$

In another case, Tolley v. Guerin ${ }^{43}$ Boyle was the trial judge. His judgment speaks of lawyer $\mathrm{Z}$ and says that $\mathrm{Z}$ while purporting to act for Tolley was really acting for Guerin. On appeal Harvey C.J. said that Boyle's criticism of $Z$ was unwarranted. ${ }^{44}$

In a number of other cases the Court of Appeal reversed Boyle J. on the facts but the Supreme Court restored him.

When Boyle died in February, 1936, Chief Justice Harvey was quoted in the Edmonton Journal of 15 February as saying "He was teaching school at Gleichen when I first knew him. Since his appointment to the bench in 1924 he has served faithfully and well and I may say that his decisions have been very acceptable to the Supreme Court of Canada which has frequently restored them after being reversed in our own Appeal Court."

Long after both Boyle and Harvey had died the former's daughter wrote an article on her father. There are a number of references to Harvey, none complimentary. ${ }^{45}$

45. See H. Boyd, Memories of J.R. Boyle, Alberta History, Summer 1982 at 9. 


\section{CONCLUSION}

Horace Harvey continued as Chief Justice of Alberta until his death on 9 September 1949 at 86 years. His contribution to the administration of justice can hardly be exaggerated. No attempt will be made to appraise it here. ${ }^{46}$

As to the problem of the Chief Justiceship, the writer's opinion is that Harvey's contention was perfectly reasonable even though the Judicial Committee rejected it. Moreover his concern to avoid the appearance of a personal quarrel with Scott was genuine and he acted with dignity.

In 1953, when the present writer was studying Chief Justice Harvey's judgments, he heard stories that Harvey and Scott came together into sittings of the Appellate Division and that Harvey sought the centre chair. In fact no such incident occurred. The writer asked S.H. McCuaig, Q.C. as to any untoward incidents. He replied emphatically that there was no public confrontation whatever and that Harvey acted with civility throughout. ${ }^{47}$

A similar opinion was expressed in a congratulatory letter of Dr. W.A.R. Kerr, Dean of Arts at the University, written on 3 September 1924. "I admired the reticence and dignity with which you treated a very rough-shod action, and later, too, your magnanimity in proposing Scott C.J. for the LL.D."

47. Pace, James Gray in Talk to My Lawyer! at 33. He describes Scott as Harvey's "hated rival." 